doi: 10.52370/TISC21299LS

\title{
USING INNOVATIVE TECHNOLOGIES TO REDUCE HEALTH RISK AND RESTORE TRAVELERS' CONFIDENCE
}

\author{
Ljiljana Stanojevic ${ }^{1}$
}

\begin{abstract}
During last year tourism and hospitality industry recorded significant losses due to the Covid-19 pandemics. One of the reasons is that indoor activities have been recognized as one of the main contributor to virus spread. Innovative technologies can play a key role in reducing indoor interaction between guests and staff, keeping social distancing, and providing a high level of cleaning standards. This research aimed to examine whether the implementation of innovative technologies may influence customers' perception of health risk and whether their implementation in hotels may lead to greater travelers' confidence in the COVID-19 era. An experimental study was conducted using online customer samples. The purposed questionnaire was developed based on preventive measures taken by leading hotels and hotel chains. The sample includes 180 examinees between 20 and 54 years of age. The results indicate that the implementation of innovative technologies in reducing contact and enhancing cleanliness have a significant impact on customers' perceived health risk and restoring travelers' confidence.
\end{abstract}

Key Words: innovative technologies, robotics, artificial intelligence, COVID-19 pandemics, health risk

JEL classification: 031,110

\section{Introduction}

The coronavirus pandemic has caused great economic damage worldwide and many industries have recorded significant losses. One of the most affected industries is tourism and hospitality since it is an industry based on human mobility and close interaction. According to the Global

\footnotetext{
${ }^{1}$ Ljiljana Stanojević, Associated Professor, Faculty of Applied Management, Economics and Finance, Jevrejska 24, 11000 Belgrade, +381641555049, 1jiljana.stanojevic@ mef.edu.rs
} 
Recovery Scenarios relished by the World Travel and Tourism Council (WTTC) in November 2020: nearly 143 million jobs worldwide are at risk, and an estimated global Travel \& Tourism GDP loss in 2020 could be USD 3,815 billion as a result of COVID-19 according to WTTC's scenario (Global Recovery Scenario, November 2020). The COVID-19 pandemic forces the global population to adjust to life under travel restrictions. In such a "new normal" the hotel industry is among the most affected by the COVID-19 pandemics since indoor activities have been recognized as one of the main contributor to virus spread (Chan et al., 2020). Today, we are still witnessing that traveling, holidays, and various events are canceled, travel restrictions are still present and as a result, hotel occupancy rates drop rapidly. According to the survey represented in Sbai (2020), conducted by Global hospitality data company STR, hotel booking dropped significantly. For example, in the first quarter of 2020 compared to 2019, Italy recorded a $96 \%$ decline in hotel booking, China 68\%, etc (Sbai, 2020). The main tourist concern, before COVID-19 pandemics was related to health risk, and health risk was always among the key factors that influence tourists' destination choice (Kozak, et al., 2007). Today this concern is greater than ever since the Covid-19 pandemic since the pandemic claimed millions of lives worldwide. Various researches indicated that tourists don't' want to visit destinations that pose a risk to their health (Fuchs \& Reichel, 2006; Visscher, 2017). The coronavirus pandemic has highlighted the issue of health and this issue will remain an important factor that will influence tourists' travel preferences even after the pandemic (Wen et al. 2020).

Table 1: Total foreign and domestic tourists' arrivals and overnight stays

\begin{tabular}{|l|c|r|r|}
\hline \multicolumn{1}{|c|}{ Value } & $\mathbf{2 0 1 9}$ & $\mathbf{2 0 2 0}$ & Decline \\
\hline Total foreign tourists`arrivals & $1,707,636$ & 424,479 & $\downarrow 75 \%$ \\
\hline Total foreign tourists` overnight stays & $3,696,193$ & $1,187,915$ & $\downarrow 68 \%$ \\
\hline Total domestic tourists`arrivals & $1,712,925$ & $1,306,900$ & $\downarrow 24 \%$ \\
\hline Total domestic tourists` overnight stays & $5,691,295$ & $4,738,695$ & $\downarrow 17 \%$ \\
\hline
\end{tabular}

Source: Statistical Office of the Republic of Serbia (2021)

Tourism and hospitality in Serbia were the first to be hit by the devastating impact of the COVID-19 pandemics. Official statistical data, that are available on web site of the Statistical Office of the Republic of Serbia, show that the number of foreign tourist arrivals from January to November 2020 decreased by $75 \%$, while the number of domestic tourists' arrivals decreased by $24 \%$, compared to the same period last year. At the same time, 
the number of overnight stays of both foreign and domestic tourists decreased by $68 \%$ and $17 \%$ respectively (Table 1 ).

The COVID-19 pandemics are forcing hoteliers to rethink their riskreduction strategies and to react more quickly to innovations. Innovative digital technologies offer a new way of interaction and communication between guests and staff, as well as a new way of cleaning. Besides various examples that show how hotels and hotel chains implemented innovative technologies, there is a lack of evidence whether the innovative hotel technologies can help the tourist to feel more secure and protected during COVID-19 pandemics.

This paper aims to examine whether the implementation of innovative technologies in hospitality can reduce customers' perceived health risks and restore travelers' confidence in the COVID-19 era. The paper has four sections. After the introduction, theoretical foundations are presented and hypotheses are developed. After that Section 3 describes the method of research. Section 4 is devoted to the results of the research on the influence of implementation of innovative technologies on customers' perceived health risk in Serbia. The limitations and areas for further research and conclusion are given at the end.

\section{Theoretical Foundations and Development of Hypothesis}

Innovative digital technologies, have been disrupted and transforming various industries sectors for years, and hoteliers recognized the benefits of those innovative technologies and their application in the hotel business processes (Zabin, 2019). Leading hotels and hotel chains already use the Internet of things (IoT), artificial intelligence (AI), robots, and other innovative technologies to attract customers. AI involves various technologies like machine learning, knowledge reasoning, natural language processing, robotics, and computer vision that can match human capabilities, particularly in the domain of learning and problem solving (Gerasimovic, et al. 2011). AI proves to be an excellent tool for analyzing complex data, and therefore is used in various practical situations (Miljković et al. 2011). To use AI technologies, lots of data have to be collected. The innovative technology providing extensive data collection is known as the Internet of Things (IoT). IoT refers to the network (public or private) of interconnected devices or embedded systems equipped with sensors and actuators ("things"). These "things" in IoT can actively 
exchange data and information over the Internet without human intervention (Stanojevic \& Radanov, 2020).

Table 2: Innovative technology in hotel services before COVID-19

\begin{tabular}{|l|c|l|}
\hline \multicolumn{1}{|c|}{ Company name } & $\begin{array}{c}\text { Type of } \\
\text { services }\end{array}$ & \multicolumn{1}{c|}{ Description } \\
\hline $\begin{array}{l}\text { CitizenM Paris, } \\
\text { Hilton, Le Bristol, } \\
\text { Village Hotels, etc. }\end{array}$ & $\begin{array}{l}\text { Rooms with } \\
\text { innovative } \\
\text { technologies }\end{array}$ & $\begin{array}{l}\text { Adjusting room temperature, lightning, } \\
\text { etc. through tablets or mobile phones, or } \\
\text { by using digital assistant: Alexa or Siri. }\end{array}$ \\
\hline $\begin{array}{l}\text { Aloft, Cosmopolitan, } \\
\text { Henna, }\end{array}$ & Artificial robots & $\begin{array}{l}\text { Robot bellperson, robot concierges, } \\
\text { assign a room to a guest, }\end{array}$ \\
\hline $\begin{array}{l}\text { Starwood Hotels, } \\
\text { Eccleston Square }\end{array}$ & Smart mirrors & Flat TVs embedded in bathroom mirrors \\
\hline $\begin{array}{l}\text { Wynn Resort in Las } \\
\text { Vegas }\end{array}$ & Voice assistant & $\begin{array}{l}\text { AI-based on natural language } \\
\text { recognition, that listen to guests needs } \\
\text { through voice commands and } \\
\text { accomplish them instantly }\end{array}$ \\
\hline $\begin{array}{l}\text { Marriot Hotels in } \\
\text { China }\end{array}$ & Facial & $\begin{array}{l}\text { Used in the hotel check-in process by } \\
\text { scanning guest face, identifies them, and } \\
\text { provides them with a key card }\end{array}$ \\
\hline Premier Inn Hotel in & $\begin{array}{l}\text { Augmented } \\
\text { reality (AR) }\end{array}$ & $\begin{array}{l}\text { AR is used to create interactive wall } \\
\text { maps. When guests point their } \\
\text { smartphones at the wall, they can access } \\
\text { more information about the local travel } \\
\text { attractions and how to get there. }\end{array}$ \\
\hline
\end{tabular}

Source: Author's research

Before the COVID-19 pandemics AI, robotics, and IoT entered hospitality in many ways to enhance customer service experience and business process automation. As indicated in Linton \& Kwortnik, (2015), customers like automated services and many hotels started to use self-service kiosks on their reception desks, so that guests can easily check-in and check out and create room keys (Ivanov \& Webster, 2017; Naumov, 2019). By implementing IoT solutions and contactless technologies hotel chains like Loews, Marriott, Hilton, and Peninsula turned their room into smart hotel rooms providing their guests with greater control over the environment. Hotel guests can adjust lights and thermostats dynamically or lock doors and more through smartphone applications and tablets (Imbardelli, 2019). Also, robots have been introduced to serve as virtual assistance to customers, to act as a concierge, or tourist help desk (Trejos, 2016). In Japan, Hennana Hotel used the robot for process automation, implementing trolleys robots to carrying guest luggage and accompanying them to their 
room. Furthermore, Hennana Hotel introduced for the same time the first humanoid robots at their reception desk (Kabadayi et al., 2019; Naumov, 2019). To deliver more personalized customer service, hoteliers use facial recognition, voice assistant, and augmented reality (Revfine, 2020). Innovative smart technologies based on AI, robots, and IoT solutions, used by hotels and hotel chains, before COVID-19 are presented in Table 2 .

In a crisis like the COVID-19 pandemics, memorable customer experiences become less important. What comes first is health and safety. Relying on innovative smart technologies hotels are in the position to promote a safer way of cleaning and interaction with hotel staff to attract guests, reduce health risk and restore customers' confidence (Ali, 2020; Fox, 2020). To respond to the pandemics, most hotels and hotel chains (Marriott International, Hilton, Choice Hotels International, Hyatt, Yotel, etc.) are enhancing safety and sanitation protocols and have started using innovative technologies like electrostatic sprayers, cleaning robots, various IoT wearable for monitoring social distancing, and various software based on artificial intelligence to ensure employees obey coronavirus health protocols proposed by World Health Organization and keep guests safe amid COVID-19 and beyond (Miller, 2020). Furthermore, UVD robots are used in Yotel, Boston to clean and disinfect guest rooms with no employee contact, as a part of smart stay safety measures (Hotel Technology News, 2020).

Deploying innovative technologies for enhancing cleanliness and reducing guest interactions may influence customer decision-making processes and associated perceived health risks (Shin \& Kang, 2020). Consumers perceived risk refers to uncertainty in decision-making that can lead to some negative outcome (Fuchs \& Reichel, 2011). More specifically as indicated in Shin \& Kang, 2020 "perceived health risk is consumer's subjective feeling of uncertainty as a result of uncontrolled events associated with terrorism, political situation, natural disasters, and pandemic". Furthermore, Yang and Nair (2014) pointed out: "tourists' risk perception is influenced by both internal and external factors". Frequently examined internal socio-demographic factors are gender, age, and income (Osland et al., 2017; Karl, 2018), and nationality and cultural orientation as cultural factors (e.g. Mariani et al., 2020, Grili et al., 2021). The research presented in this paper aimed to examine whether the implementation of innovative technologies, as an external factor, may influence customers' perception of health risk and restoring travelers' confidence. Besides concern about hygiene and safety measures, social distancing protocols can 
also influence customers' choices. The innovative technologies that can monitor social distancing among guests can make customers feel safer and have confidence in hotel management (Kim et al., 2020). Hence, the author poses the following hypothesis that customers' perception towards using innovative technologies for cleaning and social distancing in hotels during COVID-19 pandemics will rise as health risk rises (H1).

Thus, to examine customers' health risk perception, and customers' perception towards using innovative technologies for cleaning and social distancing in hotels during COVID-19 pandemics, the additional research questions were put:

RQ1: How do customers perceive the risk of COVID-19, and how do they perceive health risk?

RQ2: What are customers' perceptions towards using innovative technologies for cleaning and social distancing in hotels during COVID-19 pandemics?

RQ3: Do demographic factors affect customers' perception towards using innovative technologies for cleaning and social distancing in hotels during COVID-19 pandemics, and the health risk of coronavirus?

\section{Methodology}

This research is based on the quantitative approach. For this research, an online questionnaire was developed according to the relevant study (Shin \& Kang, 2020) to ensure content validity. Primary data collection was carried out in December 2020. The survey consists of four sections: sociodemographic questions, perception of COVID-19 (questions developed based on the previous study of Cahyanto et al., 2016), perception of health risk while visiting hotels, and perception of using innovative technologies to provide a higher level of cleanness and social distancing (questions developed based on the previous study of Shin \& Kang, 2020). Customes' attitude was measured by using a five-point Likert scale. All questions were ranked as follows: Strongly disagree (1), Disagree (2), Neither agree nor disagree (3), Agree (4), Strongly agree (5).

In the introductory part of the questionnaire, participants were asked to answer questions based on the assumption that the pandemic of COVID19 was not over and that the virus existed as a seasonal virus. All questions are related to staying at the hotel. 


\section{Results}

The total sample included 180 respondents, $51 \%$ of women and $49 \%$ of men. According to their age, the respondents were classified into the following groups: $20-30$ (38\%), 31-40 (32\%), 41-50 (20\%), above 50 (10\%). According to educational level, the respondents were classified as suggested in Neuburger \& Egger (2020): "1 - No higher school, 2 - High school or equal, 3 - College, 4 -Undergraduate degree, 5 - Graduate degree, 7 - Other degrees".

In the sample, $1 \%$ of the respondents had lower than high school education, $57 \%$ had secondary education (High school, College) and $42 \%$ had tertiary education (Undergraduate, Graduate). According to travel frequency, the respondents were divided into the following groups, as suggested in Neuburger \& Egger (2020): "1-2 times per year, 3-4 times per year, more than 5 times per year" (Table 3).

Table 3: Frequency of variables

\begin{tabular}{|l|c|c|}
\hline & n & \% \\
\hline Gender & & \\
\hline male & 92 & $51 \%$ \\
\hline female & 88 & $49 \%$ \\
\hline Age & & \\
\hline $20-34$ & 85 & $47 \%$ \\
\hline $35-50$ & 77 & $43 \%$ \\
\hline$>50$ & & $10 \%$ \\
\hline Education & 2 & \\
\hline No high school & 70 & $39 \%$ \\
\hline High school & 32 & $18 \%$ \\
\hline Collage & 53 & $29 \%$ \\
\hline Undergraduate degree & 23 & $13 \%$ \\
\hline Graduate degree & & \\
\hline Travel frequency per year & 93 & $52 \%$ \\
\hline 1-2 times & 56 & $31 \%$ \\
\hline 3-4 times & 31 & $17 \%$ \\
\hline More than 5 times & & \\
\hline
\end{tabular}

Source: Author's research

The statistical analysis was caring out in Statistical Package for Social Science (SPSS). The Kolmogorov-Smirnov test was used to test normal 
distribution and Cronbach's alpha was used for the reliability test, for each independent variable (Table 4).

Table 4: Reliability and mean values

\begin{tabular}{|l|c|c|c|}
\hline & Mean & St.Dev & $\boldsymbol{\alpha}$ \\
\hline Attitudes towards COVID-19 & $\mathbf{3 . 4 4}$ & $\mathbf{1 . 0 9}$ & $\mathbf{0 . 8 7 5}$ \\
\hline The Coronavirus (covid-19) worries me & 3.41 & 1.13 & \\
\hline $\begin{array}{l}\text { The probability that I will be infected with the } \\
\text { coronavirus is high }\end{array}$ & 3.58 & 1.04 & \\
\hline $\begin{array}{l}\text { The probability that an average person will be } \\
\text { infected with the coronavirus is high }\end{array}$ & 3.34 & 1.10 & \\
\hline Customers' health risk perception & $\mathbf{3 . 8 1}$ & $\mathbf{1 . 0 1 2}$ & $\mathbf{0 . 8 8 2}$ \\
\hline $\begin{array}{l}\text { Since many guests could carry the virus, visiting a } \\
\text { hotel could pose a risk to my health. }\end{array}$ & 4.01 & 0.98 & \\
\hline $\begin{array}{l}\text { I feel uncomfortable about visiting the hotel since } \\
\text { coronavirus is easily spread indoors. }\end{array}$ & 3.98 & 0.87 & \\
\hline $\begin{array}{l}\text { The probability of getting infected at the hotel is } \\
\text { high }\end{array}$ & 3.78 & 1.01 & \\
\hline I worry for my health during my stay in a hotel & 3.45 & 1.06 & $\mathbf{0 . 9 5 6}$ \\
\hline $\begin{array}{l}\text { Customers perceptions' towards using innovative } \\
\text { technologies for cleaning and social distancing in } \\
\text { hotels during COVID-19 pandemics }\end{array}$ & $\mathbf{3 . 7 2}$ & $\mathbf{0 . 9 1}$ & $\mathbf{0 . 8 5 6}$ \\
\hline $\begin{array}{l}\text { I would likely visit a hotel with cleaning robots } \\
\text { with advanced disinfection systems that perform } \\
\text { housekeeping tasks (Ozone and xenon UV lamps). }\end{array}$ & 4.02 & 0.91 & \\
\hline $\begin{array}{l}\text { I would likely visit the hotel with cleaning robots } \\
\text { that are engaged in maintaining hygiene. Advanced } \\
\text { disinfection options are not necessary. }\end{array}$ & 3.82 & 0.89 & \\
\hline $\begin{array}{l}\text { I would likely visit a hotel with housekeeping staff } \\
\text { that uses advanced disinfection systems (systems } \\
\text { with Ozone and xenon UV lamps). }\end{array}$ & 3.76 & 1.01 & \\
\hline $\begin{array}{l}\text { I would likely visit the hotel with the usual } \\
\text { housekeeping staff (innovative technologies are } \\
\text { not applied for disinfection). }\end{array}$ & 2.98 & 0.93 & \\
\hline $\begin{array}{l}\text { I would likely visit a hotel that provides } \\
\text { technologies for social distancing }\end{array}$ & 4.01 & 0.81 & \\
\hline Source Author's esearch & & \\
\hline
\end{tabular}

Source: Author's research

According to the results, the respondents think that the threat of Covid-19 is moderate (mean value of 3.44), but staying puts their health at a risk (mean value of 3.81). Looking closer to the values, respondents find that staying in hotels is risky since there could be many people in their 
surroundings who could carry the virus, so visiting hotels could lead to a health problem.

The mean associated with customers' perception towards using innovative technologies for cleaning and social distancing in hotels during COVID-19 pandemics indicates a positive attitude towards its implementation. A great number of respondents agree that they would visit hotels with advanced cleaning technologies and technologies for social distancing, with a mean closer to the maximum. At the same time, they find robots more reliable in housekeeping tasks than hotel staff.

To answer research question 3, one-way ANOVA was used to determine whether there was any significant mean difference in

[1] Perception of COVID-19,

[2] Health risk perception while visiting hotels, and

[3] Perception towards using innovative technologies for cleaning and social distancing, regarding age, education, and travel frequencies.

The results for age groups are presented in Table 5. Tukey's post hoc test was conducted to assess which age group showed the significant difference.

Table 5: ANOVA results for age groups

\begin{tabular}{|l|c|c|c|c|c|c|c|c|c|c|}
\hline & \multicolumn{4}{|c|}{ Age groups } & \multicolumn{4}{c|}{ post hoc comparisons } \\
\hline & \multicolumn{2}{|c|}{$\mathbf{2 0 - 3 4}$} & \multicolumn{2}{|c|}{$\mathbf{3 5 - 5 0}$} & \multicolumn{2}{c|}{$\mathbf{5 0}$} & & $\mathbf{1 ~ - 2}$ & $\mathbf{1 ~ - 3}$ & $\mathbf{2 ~ - 3}$ \\
\hline & M & StDev & M & StDev & M & StDev & p & $\mathrm{p}$ & $\mathrm{p}$ & $\mathrm{p}$ \\
\hline$[1]$ & 3.34 & 1.10 & 3.41 & 1.13 & 3.58 & 1.04 & 0.000 & 0.651 & 0.001 & 0.000 \\
\hline$[2]$ & 3.43 & 1.134 & 3.62 & 1.311 & 3.86 & 1.345 & 0.000 & 0.752 & 0.000 & 0.002 \\
\hline$[3]$ & 4,01 & 0.816 & 3.93 & 1.115 & 4.1 & 0.756 & 0.102 & 0.192 & 0.091 & 0.103 \\
\hline
\end{tabular}

Source: Author's research

The results revealed a significant difference in age group $(\mathrm{p} \leq 0.01)$ demonstrating that older respondents express greater concern toward covid-19 and the threat it poses to their health than younger ones. On the other hand, the impact of age on the respondents' perception towards using innovative technologies for cleaning and social distancing was not significant.

The results for educational groups are presented in Table 6. Tukey's post hoc test was used to assess which educational group showed the significant difference. 
Table 6: ANOVA results for education group

\begin{tabular}{|c|c|c|c|c|c|c|c|c|c|c|}
\hline & \multicolumn{6}{|c|}{ Education } & & \multicolumn{3}{|c|}{ post hoc comparisons } \\
\hline & \multicolumn{2}{|c|}{$\begin{array}{c}\text { Lower sec. } \\
\text { ed. (1) }\end{array}$} & \multicolumn{2}{|c|}{\begin{tabular}{|c|} 
High sec. ed. \\
$(2)$
\end{tabular}} & \multicolumn{2}{|c|}{$\begin{array}{c}\text { Tertiary } \\
\text { education (3) }\end{array}$} & & $1-2$ & $1-3$ & $2-3$ \\
\hline & $\mathrm{M}$ & StDev & $\mathrm{M}$ & StDev & $\mathrm{M}$ & & $\mathrm{p}$ & $\mathrm{p}$ & $\mathrm{p}$ & $\mathrm{p}$ \\
\hline [1] & 3.42 & 0.506 & 3.49 & 0.411 & 3.69 & 0.951 & 0.003 & 0.543 & 0.002 & 0.001 \\
\hline [2] & 3.43 & 1.124 & 3.62 & 1.221 & 3.86 & 1.345 & 0.002 & 0.423 & 0.001 & 0.003 \\
\hline [3] & 3,1 & 0.716 & 3.93 & 1.315 & 4.01 & 0.556 & 0.001 & 0.655 & 0.001 & 0.000 \\
\hline
\end{tabular}

Source: Author's research

The results revealed that the impact of education is significant and respondents with the highest education show more concern about COVID19 and the risk it poses to health. The impact of education on the respondents' perception towards using innovative technologies for cleaning and social distancing was also significant. Respondents with the highest-level education were looking for an innovative and safer way of cleaning and social distancing than the less educated ones.

Table 7 represents ANOVA and Tukey's post hoc comparison that was used to discover whether there is a significant difference among different travel frequency groups.

Table 7: ANOVA results for travel frequency

\begin{tabular}{|c|c|c|c|c|c|c|c|c|c|c|}
\hline & \multicolumn{6}{|c|}{ Travel frequency per year } & & \multicolumn{3}{|c|}{ post hoc comparisons } \\
\hline & \multicolumn{2}{|c|}{ 1-2 times (1) } & \multicolumn{2}{|c|}{ 3-4 times (2) } & \multicolumn{2}{|c|}{$\begin{array}{c}\text { More than } 5 \\
\text { times (3) }\end{array}$} & \multirow[b]{2}{*}{$P$} & \multirow{2}{*}{$\begin{array}{c}1-2 \\
p\end{array}$} & \multirow{2}{*}{$\begin{array}{c}1 \text { - } 3 \\
p\end{array}$} & \multirow{2}{*}{$\begin{array}{c}2-3 \\
p\end{array}$} \\
\hline & M & StDev & $\mathrm{M}$ & Dev & M & StDev & & & & \\
\hline [1] & 3.41 & 0.606 & 3.11 & 0.488 & 2.79 & 0.841 & 0.00 & 0.234 & 0.001 & 0.001 \\
\hline [2] & 3.11 & 1.113 & 3.02 & 1.121 & 2.86 & 0.945 & 0.0 & 0.1 & 0.002 & 0.001 \\
\hline [3] & 4.1 & 0.816 & 3.93 & 1.115 & 4.01 & 0.756 & 0.132 & 0.416 & 0.201 & 0.067 \\
\hline
\end{tabular}

Source: Adapted form Neuburger \& Egger (2020)

Results revealed that respondents that frequently travel express less concern regarding covid-19 than those that travel less and do not insist on innovative technologies for cleaning and social distancing.

Table 8: Pearson correlation

\begin{tabular}{|c|c|c|c|}
\hline Pairs & Coefficient & N & p \\
\hline $\begin{array}{c}\text { Preference for innovative technologies/ } \\
\text { perceived health risk of Covid-19 }\end{array}$ & 0.75 & 180 & 0.000 \\
\hline
\end{tabular}

Source: Author's research 
Starting hypothesis was tested by Pearson correlation (Table 8).

The preference for innovative technologies has a high and positive relationship with the perceived health risk of COVID-19 (Table 8). The stated data are in line with H1, according to which: that customers' perception towards using innovative technologies for cleaning and social distancing in hotels during COVID-19 pandemics will rise as health risk rise $(\mathrm{H} 1)$.

\section{Discussion}

Innovative technologies like AI, robotics, and IoT have been used in hospitality long before COVID-19 pandemics, to enhance customer service experience and business process automation and many authors foresee large utilization of these innovative technologies in tourism and hospitality in years to come (Cain et al. 2019; Ivanov, 2020; Shin \& Kang, 2020). This research aimed to examine whether the implementation of innovative technologies for cleaning and social distancing has an impact on customers' perceived health risk during COVID-19 pandemics. The research was conducted in December 2020 during the third wave of coronavirus in Serbia. The results of this research indicated that the covid-19 pandemic put innovative technologies for cleaning and social distancing in front of human service (same in Kim et al. 2020, Shin \& Kang, 2020), but different from most studies that were conducted before COVID-19 pandemics (Kattara, 2013; Choi et al. 2020; Ivanov et al. 2020). The threat to humans health caused by coronavirus pandemics influenced the acceptance of innovative technologies for cleaning and social distancing as means for reducing customers' perceived health risk.

When faced with various uncontrolled events, customers' may perceive health risks differently in different situations (Bentley \& Page, 2008). This study revealed that pandemic influenced by a coronavirus (Sars-cov-2, or covid-19) has a consequential effect on tourists. The respondents associate staying in a hotel with a higher degree of health risk. When the perception of health risk is high, the customers express more tendencies towards innovative technologies for cleaning and social distancing. This is consistent with the findings of Shin \& Kang, 2020, and Kim et al. 2020. After COVID-19 pandemics, customers' preferences may change, so that human service becomes more acceptable for customers over innovative technologies. To attract customers and restore their confidence, during and after COVID-19 pandemics, hoteliers need to adapt their business process 
and ensure that customers feel a greater sense of safety. Innovative technologies for cleaning like xenon UV light disinfection systems and Ozone disinfection systems will be important for decreasing customers' health risks. Since there is a great fluctuation of hotel visitors there is a need for advanced disinfection in rooms as well as in other hotel areas. Furthermore, various smart-stay safety measures are needed to keep guests safe, like various IoT wearable for monitoring social distancing, and various software based on artificial intelligence to ensure employees obey coronavirus health protocols.

Implementation of innovative technologies is not without challenges. High cost, low-touch service experiences, and loss of employment are among them. While high cost should be considered as a long-term investment, an innovative managerial approach is needed to overcome the loss of employment. During COVID-19 pandemics remote working becomes the norm. Innovative technologies and Cloud-based software can transfer some hotel jobs to remote work such as sales-related jobs, digital marketing, ecommerce, etc. Innovative technologies are an industrial trend in hospitality, so creative solutions have to be found for hotel employees in the future.

\section{Limitations and Areas for Further Research}

This paper aimed to point out the importance of the usage of innovative technologies for decreasing customers' perception of health risk during COVID-19 pandemics. Further research is needed to investigate customers' reactions to the application of innovative technologies, not only during COVID-19 pandemics but beyond. This research focused on the influence of demographic factors (age, education) on perceived health risk and perception toward using innovative technologies in cleaning and social distancing. In the future additional research is needed to investigate the influence of other factors like cultural backgrounds of hotel customers, travelers' behavior, etc. on customers' perception toward innovative technologies and their use in the presented context.

\section{Conclusion}

Innovative digital technologies offer a new way of interaction and communication between guests and staff, as well as a new way of cleaning. They offer advanced disinfection ability and can help customers to feel safer while staying in the hotel. Furthermore, an intelligent indoor solution 
like IoT controllable devices can offer a lower cost of running operations of hotel rooms. Although some of these technologies have been explored and adopted by some leading hotels, nowadays its implementation becomes more important as hotels are facing lower occupancy due to the COVID19 pandemics.

The results show that customers' preferences for innovative technologies have a high and positive relationship with the perceived health risk of COVID-19. Furthermore, results show that demographic factors (e.g., age, education) have no significant impacts on perceived health risk, and while age has no significant factor on perception towards using innovative technologies in cleaning and social distancing, education and travel frequency do. Respondents with the highest education seek an innovative and safer way of cleaning and social distancing than the less educated ones. Results also revealed that respondents that frequently travel express less concern regarding covid-19 than those that travel less and do not insist on innovative technologies for cleaning and social distancing.

These findings could be used in hospitality industries for further promotions and to restore customers' confidence and ensure customers continue to use their services.

\section{References}

1. Ali, N., (2020). How location technologies facilitate safer holiday hotel stays, https://www.hotelmanagement.net/tech/location-technologiesfacilitate-safer-holiday-hotel-stays, (15 January 2021).

2. Bentley, T.A., Page, S.J., (2008). A decade of injury monitoring in the New Zealand adventure tourism sector: a summary risk analysis. Tourism Management, Vol. 29, No. 5, 857-869.

3. Cahyanto, I., Wiblishauser, M., Pennington-Gray, L., Schroeder, A. (2016). The dynamics of travel avoidance: The case of Ebola in the US. Tourism Management Perspectives, Vol. 20, 195-203.

4. Cain, L. N., Thomas, J. H., Alonso Jr, M. (2019). From sci-fi to sci-fact: the state of robotics and AI in the hospitality industry. Journal of Hospitality and Tourism Technology. Vol. 10 No. 4, 624-650 
5. Chan, J.F.W., Yuan, S., Kok, K.H., To, K.K.W., Chu, H., Yang, J., Xing, F., Liu, J., Yip, C.C.Y., Poon, R.W. S., Tsoi, H.W. (2020), "A familial cluster of pneumonia associated with the 2019 novel coronavirus indicating person-to-person transmission: a study of a family cluster", The Lancet, Vol. 395 No. 10223, 514-523.

6. Choi, Y., Mehraliyev, F., Kim, S. S. (2020). Role of virtual avatars in digitalized hotel service. International Journal of Contemporary Hospitality Management.

7. Grilli, G., Tyllianakis, E., Luisetti, T., Ferrini, S., \& Turner, R. K. (2021). Prospective tourist preferences for sustainable tourism development in Small Island Developing States. Tourism Management, 82, 104178.

8. Fox, J. T. (2020), LG to launch disinfecting robot, https://www.hotel management.net/tech/lg-to-launch-disinfecting-robot-at-digital-ces January 2021).

9. Fuchs, G., Reichel, A. (2011). An exploratory inquiry into destination risk perceptions and risk reduction strategies of first-time vs. repeat visitors to a highly volatile destination. Tourism Management, Vol. 32, No. 2, 266276.

10. Gerasimovic, M., Stanojevic, Lj., Bugaric, U., Miljkovic, Z., Veljovic, A., (2011). Using Artificial Neural Networks for Predictive Modeling of Graduate's Professional Choice, New Educational Review, Vol. 23, No. 2011, 175-188,

11. Global Recovery Scenarios 2020 Updates, https://wttc.org/Research/ Economic-Impact/Recovery-Scenarios, (15 January 2021)

12. Hotel Technology News, (2020), YOTEL Boston Deploys Autonomous Disinfection Robots to Reinforce Guest Safety. https://hoteltechnology news.com/2020/09/yotel-boston-deploys-autonomous-disinfection-robotsto-reinforce-guest-safety/ (15 January 2021)

13. Imbardelli, A. P. (2019), How smart rooms can transform hotel brands, https://www.hotelmanagement.net/tech/how-smart-rooms-can-transformhotel-brands (15 January 2021) 
14. Ivanov, S. H., Webster, C. (2017). Adoption of robots, artificial intelligence, and service automation by travel, tourism, and hospitality companies-a cost-benefit analysis. Artificial Intelligence and Service Automation by Travel, Tourism and Hospitality Companies-A Cost-Benefit Analysis. https://papers.ssrn.com/sol3/papers.cfm?abstract_id=3007577 (January 2021).

15. Ivanov, S., (2020). The impact of automation on tourism and hospitality jobs. Information Technologies in Tourism, Vol. 22, No. 2, 205-215.

16. Kabadayi, S., Ali, F., Choi, H., Joosten, H., Lu, C. (2019). Smart service experience in hospitality and tourism services. Journal of Service Management. Vol. 30, No. 3, 326-348

17. Kattara, H. S., El-Said, O. A. (2013). Customers' preferences for new technology-based self-services versus human interaction services in hotels. Tourism and Hospitality Research, Vol. 13, No. 2, 67-82.

18. Kim, S. S., Kim, J., Badu-Baiden, F., Giroux, M., Choi, Y. (2020). Preference for robot service or human service in hotels? Impacts of the COVID-19 pandemic. International Journal of Hospitality Management, Vol. 93, 102795.

19. Kozak, M., Crotts, J.C., Law, R., (2007). The impact of the perception of risk on international travelers. International Journal of Tourist Research. Vol. 9, No. 4, 233-242.

20. Law, R. (2006). The perceived impact of risks on travel decisions. International Journal of Tourism Research, Vol. 8, No. 4, 289-300.

21. Lepp, A., Gibson, H. (2003). Tourist roles, perceived risk, and international tourism. Annals of tourism research, Vol. 30, No. 3, 606-624.

22. Linton, H., Kwortnik, R. J. (2015). The mobile revolution is here: are you ready? Cornell Hospitality Reports, Vol. 15, No. 6, 6-18.

23. Mariani, M. M., Borghi, M., \& Okumus, F. (2020). Unravelling the effects of cultural differences in the online appraisal of hospitality and tourism services. International Journal of Hospitality Management, 90, 102606. 
24. Miljković, Z., Gerasimović, M., Stanojević, Lj., Bugarić, U., (2011), Using Artificial Neural Networks To Predict Professional Movements Of Graduates, Croatian Journal of Education, Vol: 13 No. (3/2011), pages: 117-141.

25. Miller, D., (2020). Hotels enhance cleaning protocols in light of COVID-19, https://www.hotelnewsnow.com/Articles/302702/Hotelsenhance-cleaning-protocols-in-light-of-COVID-19 (15 January 2021)

26. Naumov, N. (2019). The impact of robots, artificial intelligence, and service automation on service quality and service experience in hospitality. Robots, Artificial Intelligence, and Service Automation in Travel, Tourism, and Hospitality, Emerald Publishing Limited, 123-133.

27. Neuburger, L., \& Egger, R. (2020). Travel risk perception and travel behavior during the COVID-19 pandemic 2020: a case study of the DACH region. Current Issues in Tourism, 1-14.

28. Osland, G. E., Mackoy, R., \& McCormick, M. (2017). Perceptions of personal risk in tourists' destination choices: nature tours in Mexico. European Journal of Tourism, Hospitality, and Recreation, Vol. 8, No. 1, $38-50$.

29. Revfine. (2020). Retrieved from: https://www.revfine.com/facialrecognition-hospitality-industry/ (December 2020).

30. Sbai, A., (2020). How COVID-19 Impacted Travel \& Tourism Industry Globally, https://infomineo.com/covid-19-impacted-travel-tourismindustry/ (15 January 2021)

31. Shin, H., Kang, J. (2020). Reducing perceived health risk to attract hotel customers in the COVID-19 pandemic era: Focused on technology innovation for social distancing and cleanliness. International Journal of Hospitality Management, Vol. 91, 102664.

32. Stanojević, Lj., Radanov, P., (2020), Digital transformation of work will Covid-19 pandemic influence intelligent automation of work, International Scientific \& Professional Conference MEFKON20, Innovation As An Initiator Of The Development "Innovations in the Function of Development", International Thematic Monograph - Thematic Proceedings, 55-70. 
33. Statistical Office of the Republic of Serbia (2021) https://data.stat. gov.rs/Home/Result/220203? languageCode=sr-Latn (15 January 2021)

34. Trejos, N. (2016). Introducing Connie, Hilton's New robot concierge. https://eu.usatoday.com/story/travel/roadwarriorvoices/2016/03/09/introd ucingconnie-hiltons-new-robot-concierge/81525924/ (15 January 2021)

35. Wen, J., Liu, X. Yu, C. (2020), "Exploring the roles of smart services in Chinese senior tourists' travel experiences: an application of psychological reactance theory", Anatolia.

36. Williams, A. M., Baláž, V. (2015). Tourism risk and uncertainty: Theoretical reflections. Journal of Travel Research, Vol. 54, No. 3, 271287.

37. Yang, E. C. L., Nair, V. (2014). Tourism at risk: A review of risk and perceived risk in tourism. Asia-Pacific Journal of Innovation in Hospitality and Tourism (APJIHT), Vol. 3, No. 2, 1-21.

38. Yang, E. C. L., Khoo-Lattimore, C., Arcodia, C. (2017). A systematic literature review of risk and gender research in tourism. Tourism Management, Vol. 58, 89-100.

39. Zabin, J. (2019), "Artificial intelligence: working hand in hand with hotel staff", https://hoteltechnologynews.com/2019/07/artificialintelligence-working-hand-in-hand-with-hotel-staff/ (15 January 2021) 